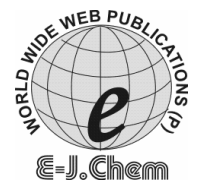

http://www.e-journals.net
ISSN: 0973-4945; CODEN ECJHAO

E-Journal of Chemistry 2009, 6(S1), S21-S24

\title{
UV Spectrophotometric Method for Determination of Cinitapride in Pure and its Solid Dosage Form
}

\author{
B. THANGABALAN ${ }^{*}$, A. ELPHINE PRABAHAR \\ R. KALAICHELVI ${ }^{\S}$ and P. VIJAYARAJ KUMAR ${ }^{\#}$ \\ *SIMS College of Pharmacy, Mangaladas Nagar, Guntur-522 001, India. \\ Department of Pharmacy, \\ Donbosco PG College, Vatticherukuru Mandal, Guntur-522 017, India. \\ ${ }^{\S}$ K.C.Reddy Institute of Pharmaceutical Sciences, \\ Jangamguntla Palem, Medikonduru Mandal, Guntur-522 348, India. \\ "Bharat Institute of Pharmacy, Mangalpally Village, \\ Ibrahimpatnam. RR Dist.-501506, India. \\ bthangabalan@gmail.com
}

Received 12 April 2009; Accepted 5 June 2009

\begin{abstract}
A new, rapid, precise, accurate and sensitive analytical method was developed for the UV spectrophotometric assay of cinitapride (CTP). The drug obeyed the Beer's law and showed good correlation. It showed absorption maxima at $260 \mathrm{~nm}$ in methanol. The linearity was observed between $5-40 \mu \mathrm{g} \mathrm{mL}^{-1}$. The results of analysis were validated by recovery studies. The recovery was more than $99 \%$. The proposed method is the only method available for spectrophotometric determination of the drug. It is simple, precise, sensitive and reproducible and can be used for the routine quality control testing of the marketed formulations.
\end{abstract}

Keywords: UV Spectrophotometry, Cinitapride and Tablet analysis.

\section{Introduction}

Cinitapride, chemically 4-amino- $N$-[3-(Cyclohexan-1-yl-methyl)-4-piperidinyl]-2-ethoxy-5nitrobenzamide (Figure 1), is a substituted benzamide gastroenteric prokinetic agent acting via complex, but synergistic effects on serotonergic 5-HT2 (inhibition) and 5-HT4 (stimulation) receptor and dopaminergic D2 (inhibition) receptors in the neuronal synapses of the myenteric plexi $^{1-3}$. A survey of literature revealed a polarographic method ${ }^{4}$ and LC-MS/MS methods for its determination in plasma ${ }^{4,5}$. No spectrophotometric method has been reported so far. Hence an attempt was made to develop simple and economical spectrophotometric methods with greater precision, accuracy, and sensitivity for the analysis of CTP in tablets. 


\section{Experimental}<smiles>CCOc1cc([N+](=O)[O-])c([N+](=O)[O-])cc1C(=O)NC1CCN(CC2CC=CCC2)CC1</smiles>

Figure 1. Chemical structure of cinitapride.

The spectrophotometric measurements were carried out using An Elico UV/Visible double beam spectrophotometer SL-164 with $1 \mathrm{~cm}$ matched quartz cells.

\section{Reagents}

CTP was tested for purity by measuring its melting point and IR spectra and no impurities were found. Methanol used were of analytical grade.

\section{Standard solutions}

Standard stock solution of CTP $\left(1000 \mu \mathrm{g} \mathrm{mL}^{-1}\right)$ was prepared in methanol. It was further diluted to obtain 5, 10, 20, 30 and $40 \mu \mathrm{g} \mathrm{mL}^{-1}$ with methanol. The absorbance was measured at $260 \mathrm{~nm}$ against methanol as blank. The calibration curve was plotted in the concentration range of 5 to $40 \mu \mathrm{g} \mathrm{mL}^{-1}$ of CTP in methanol.

\section{Procedure for tablets}

Twenty tablets were weighed accurately and triturated to fine powder. The powder equivalent to $10 \mathrm{mg} \mathrm{CTP}$ was weighed and transferred to $25 \mathrm{~mL}$ volumetric flask. To this $15 \mathrm{~mL}$ of methanol was added and sonicated for 15 minutes, then filtered through Whatman No. 42 filter paper. The residues were washed thoroughly with methanol and further diluted with methanol to $20 \mu \mathrm{g} \mathrm{mL}^{-1}$ concentration and the absorbance measured at $260 \mathrm{~nm}$ against methanol as a blank.

\section{Results and Discussion}

The UV spectrum of standard solutions of CPT in methanol was illustrated in Figure 2. The optical characteristics such as Beer's Law limit, molar absoptivity, Sandell's sensitivity, slope and intercept are summarized in Table 1. The assay and precision studies results for tablets containing CPT are shown in Table 2.

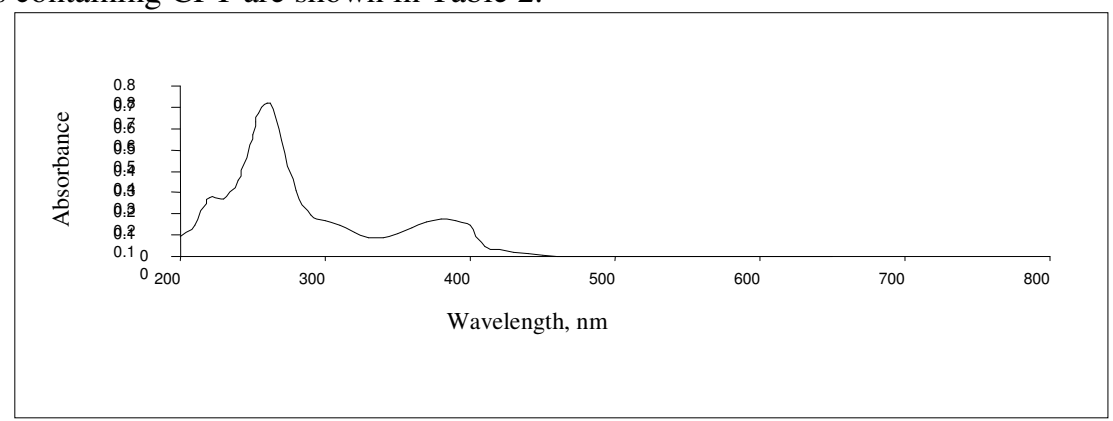

Figure 2. UV spectrum of cinitapride in methanol. 
Table 1. Optical characteristics of proposed method.

\begin{tabular}{lll}
\hline Parameters & Values \\
\hline$\lambda_{\text {max }}, \mathrm{nm}$ & 260 \\
Beer's law limit, $\mu \mathrm{g} \mathrm{mL} \mathrm{m} \mathrm{cm}^{-1}$ & $5-40$ \\
Sandell's sensitivity, $\mu \mathrm{g} \mathrm{cm}^{-2} / 0.001$ absorbance unit & $2.5 \times 10^{-5}$ \\
Molar absorptivity, $\mathrm{L} \mathrm{mol}^{-1} \mathrm{~cm}^{-1}$ & & $1.7911 \times 10^{4}$ \\
Regression equation $(\mathrm{Y}=\mathrm{a}+\mathrm{bc})$ & & \\
& Slope (b) & 0.0239 \\
& Intercept (a) & 0.0082 \\
Correlation coefficient $\left(\mathrm{r}^{2}\right)$ & & 0.9994 \\
\hline
\end{tabular}

\section{Validation}

The assay of CPT was validated with respect to stability, linearity, precision and accuracy.

\section{Stability}

The standard stock solutions of CPT were stored, in two different conditions, at $\pm 4{ }^{\circ} \mathrm{C}$ and at ambient temperature for one month. During this period, the solutions were analyzed with UV spectrophotometric method, the spectrum was compared with the spectrum of daily prepared standard solution, and no difference was obtained between them. It is decided that CPT is highly stable in the mentioned conditions.

\section{Linearity and range}

In developed UV method, calibration curve was linear in the range from 5 to $40 \mu \mathrm{g} \mathrm{mL}^{-1}$ of CPT.

\section{Precision}

\section{Inter-day precision}

This was done by analyzing formulation by same analyst for six days subsequently. The $\%$ RSD values are shown in Table 2.

\section{Intra-day precision}

This was done by analyzing formulation in same day for six times of individual preparation and observation. The \% RSD and datas are shown in Table 2.

Table 2. Assay results and precision studies.

\begin{tabular}{|c|c|c|c|c|c|c|}
\hline \multirow[b]{2}{*}{ Sample } & \multirow{2}{*}{$\begin{array}{c}\text { Labeled } \\
\text { amount } \\
\mathrm{mg} / \mathrm{tab}\end{array}$} & \multirow{2}{*}{$\begin{array}{c}\text { Amount } \\
\text { found in } \\
\mathrm{mg}^{*}\end{array}$} & \multirow{2}{*}{$\begin{array}{c}(\%) \text { label } \\
\text { claim* } \pm \text { S.D }\end{array}$} & \multicolumn{3}{|c|}{ Precision** } \\
\hline & & & & Repeatability & Inter-day & Intra-day \\
\hline Cinitapride & 1 & 1.006 & $100.54 \pm 0.293$ & 0.471 & 0.0349 & 0.0298 \\
\hline
\end{tabular}

\section{Accuracy}

To ensure the accuracy and reproducibility of the results obtained, known amounts of pure drug was added to the previously analysed formulated samples and these samples were reanalyzed by the proposed method and also performed recovery experiments. The percentage recoveries thus obtained were given in Table 3. 
Table 3. Recovery study.

\begin{tabular}{ccccccc}
\hline \multirow{2}{*}{ Drug } & $\begin{array}{c}\text { Label } \\
\text { Claim, } \\
\mathrm{mg} / \mathrm{tab}\end{array}$ & $\begin{array}{c}\text { Estimated } \\
\text { Amount, } \\
\mathrm{mg} / \mathrm{tab}\end{array}$ & $\begin{array}{c}\text { Spike } \\
\text { Level, } \\
\%\end{array}$ & $\begin{array}{c}\text { Amount } \\
\text { of drug } \\
\text { added, mg }\end{array}$ & $\begin{array}{c}\text { Amount } \\
\text { of drug } \\
\text { recovered, mg }\end{array}$ & $\begin{array}{c}\text { Percentage } \\
\text { recovery } \pm \text { SD* }\end{array}$ \\
\hline $\begin{array}{l}\text { Cinitapride } \\
\text { tablets }\end{array}$ & 1 & \multirow{2}{*}{1.006} & 80 & 8.0 & 8.02 & $100.28 \pm 0.3374$ \\
& & & 100 & 10.0 & 9.99 & $99.97 \pm 0.2967$ \\
& & 120 & 12.0 & 12.01 & $100.09 \pm 0.5428$ \\
\hline
\end{tabular}

*Mean of six determinations.

\section{Conclusions}

The proposed method is found to be rapid, precise, accurate and sensitive. The statistical parameters and recovery study data clearly indicate the reproducibility and accuracy of this method. Analysis of the authentic sample containing CPT showed no interference from the common excipients. Hence, these methods could be considered for the determination of CPT in the quality control laboratories.

\section{Acknowledgement}

The authors are thankful to Don Bosco College of Pharmacy for providing the facilities to carryout this study. The authors are also thankful to Dr. S.A. Azeez, Principal, SIMS College of Pharmacy to his valuable suggestion during this research work.

\section{References}

1. Roberts D J, Curr Ther Res., 1982, 31, S1-S44.

2. Fernandez A G and Massingham R, Life Sci., 1985, 36, 1-14.

3. Massingham R, Bou J and Roberts D J, J Auton Pharmacol., 1985, 5, 41-53.

4. Gonzalez M I, Gonzalez P C and Blanco Lopez M A, Analytica Chimica Acta,1998, 368, 175-181.

5. Roy S M N, Yetal S M, Chavan S V, Pradhan V R and Joshi S S, E Journal of Chemistry, 2008, 5, 453-460. 


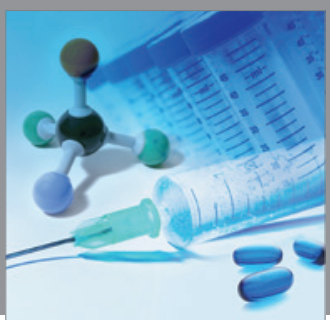

International Journal of

Medicinal Chemistry

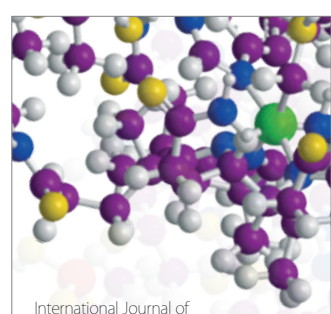

Carbohydrate Chemistry

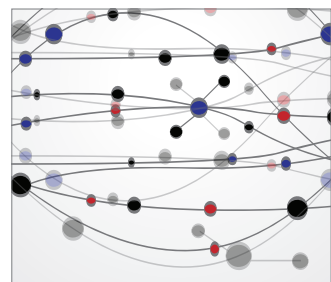

The Scientific World Journal
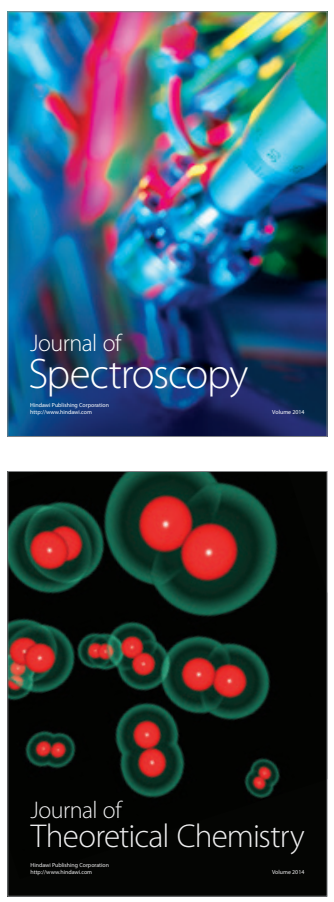
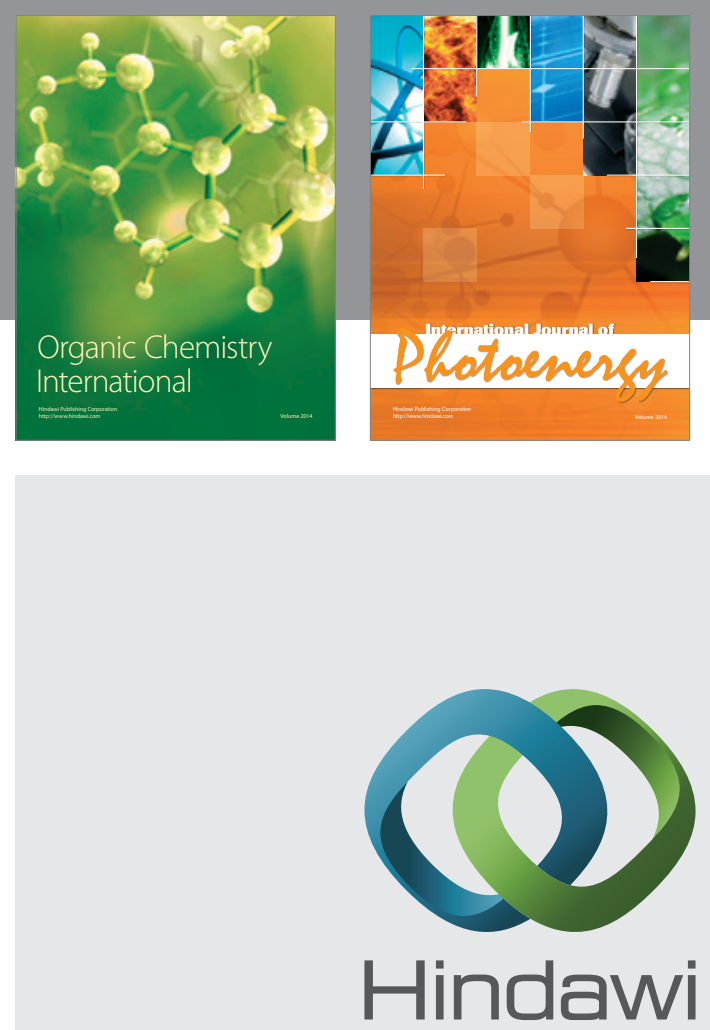

Submit your manuscripts at

http://www.hindawi.com
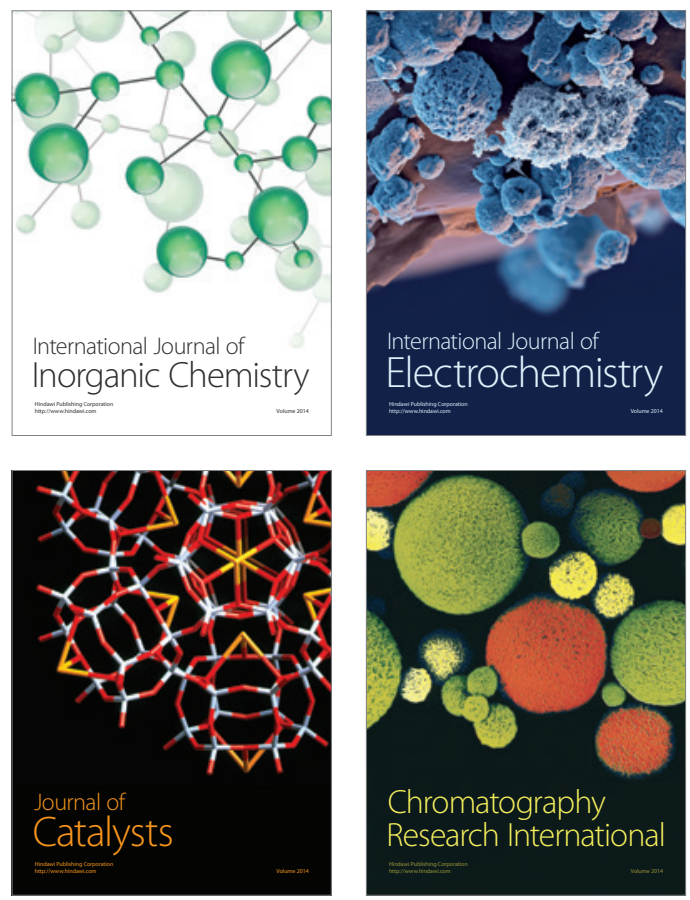
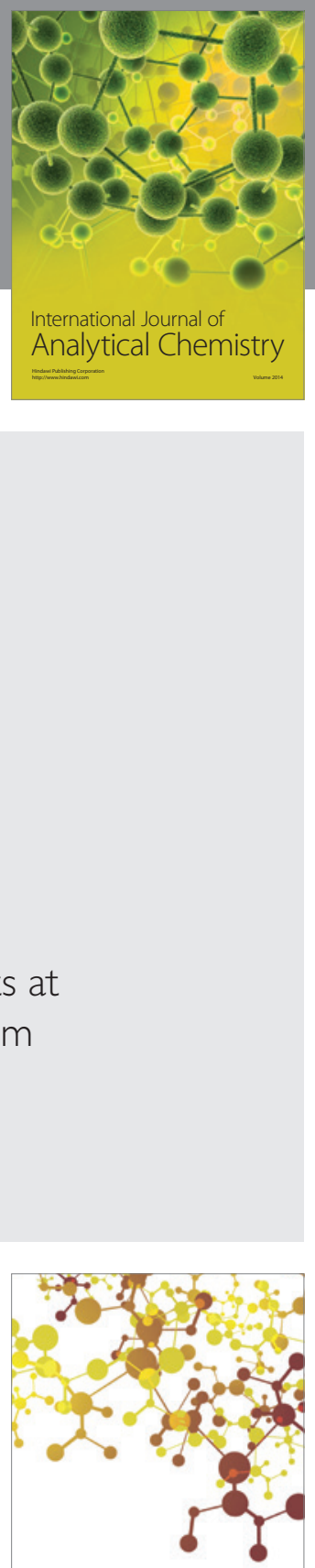

Journal of

Applied Chemistry
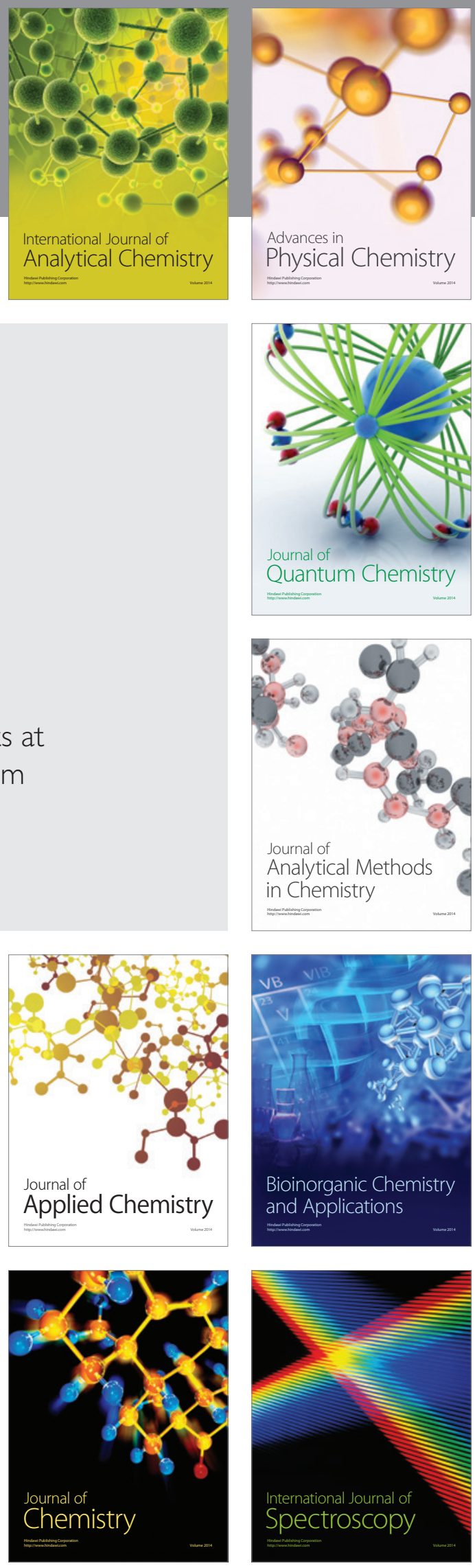